\title{
Bladder Cancer pN2 TNM Finding v7
}

National Cancer Institute

\section{Source}

National Cancer Institute. Bladder Cancer pN2 TNM Finding v7. NCI Thesaurus. Code C89359.

Bladder cancer with multiple regional lymph node metastases in the true pelvis (hypogastric, obturator, external iliac, or presacral lymph node metastasis). (from AJCC 7th Ed.) 